\title{
Evaluation of exotic wheat (Triticum aestivum L.) genotypes for heat tolerance on the basis of physiological phenotyping
}

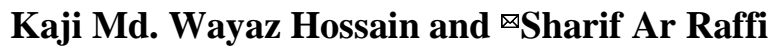

Department of Genetics \& Plant Breeding, Bangladesh Agricultural University, Mymensingh-2202, Bangladesh

\begin{tabular}{|c|c|}
\hline ARTICLE INFO open ${ }^{\text {AcCEss }}$ & $t$ \\
\hline $\begin{array}{l}\text { ovember } 2018 \\
\text { ecember } 2018 \\
\text { ecember } 2018\end{array}$ & \multirow{3}{*}{$\begin{array}{l}\text { Plant physiological parameters such as membrane thermostability, canopy temperature depression, leaf } \\
\text { chlorophyll content and yield related traits like no. of spikelets per spike, no. of grains per spike, 200-grain } \\
\text { weight and grain yield of } 18 \text { wheat genotypes were carried out to assess for heat tolerance. Performances } \\
\text { of all the genotypes were found to have significant differences for all the traits except canopy temperature } \\
\text { depression. But, canopy temperature depression with some other traits like leaf chlorophyll content, no. of } \\
\text { grains per spike, 200-grain weight and grain yield per plant demonstrated significant differences when it } \\
\text { grown in heat stress condition. In general, genotypes with higher leaf chlorophyll content and enhanced } \\
\text { membrane thermostability demonstrated higher } 200 \text {-grain weight or grain yield. Besides, in spite of } \\
\text { having heat tolerant traits, several genotypes performed poor due to their poor genotypic potential. The } \\
\text { present investigation has successfully isolated several genotypes viz. H024, H023, H022 and H018 with } \\
\text { desirable traits related to heat tolerance based on overall performance while grown under heat stress. } \\
\text { These genotypes can be used as gene source for future breeding program to improve heat tolerance of the } \\
\text { local wheat cultivars. }\end{array}$} \\
\hline & \\
\hline & \\
\hline
\end{tabular}

(O2018 by authors and BAURES. This work is licensed under the Creative Commons Attribution International License (CC By 4.0).

\section{Introduction}

Wheat (Triticum aestivum L.) is an important cereal crop, grown in wide range of environments in the world (FAO, 2013). In Bangladesh, wheat varieties give almost $50 \%$ lower yield than the potential yield (Sikder et al., 2010). Among the many other reasons, heat stress is one of the vital constrains for $50 \%$ less production (Fischer, 1985). Because, optimum temperature range for wheat cultivation is $18-24^{\circ} \mathrm{C}$ (Bahar et al., 2011) and for anthesis, grain filling is 12 to $22^{\circ} \mathrm{C}$. Above the optimum temperature range is generally known as heat stress (Wahid et al., 2007). Wheat faces heat stress problem due to abrupt increase of daily temperature, late sowing and short winter season. Global climate models predict an increase of mean annual temperatures between 1.5 and $6.0^{\circ} \mathrm{C}$ by the year of 2100 (IPCC, 2013), whereas in Bangladesh it will be increased by $0.39^{\circ} \mathrm{C}$ in 2100 (Karmakar et al., 2000). In Bangladesh, wheat plants received the sudden high temperature stress from the very beginning of March or just after end of winter season when plant reaches to grain filling stage. Whereas, with every $1^{\circ} \mathrm{C}$ increase in temperature from $28^{\circ} \mathrm{C}$ during grain filling period results $3-4 \%$ yield reduction (Reynolds et al. 1994, 1998; Wardlaw et al., 1989). Another important problem is getting short winter period due to late planting of wheat, which consequently exposed wheat plants to heat stress and offers short grain filling period. Stone and Nicolas (1994) found that even 5 to 6 days short periods cause $20 \%$ or more yield losses in wheat. The consequences for imposing heat stress are shortening grain filling duration (Yang et al., 2002), inducing early flag leaf (Yang et al., 2002), acceleration of grain filling activities (Paulsen, 1994), improper grain filling (Reynolds et al., 2001; Rane et al. 2007), constriction of carbon assimilation (Stone, 2001), floret abortion (Wardlaw and Wrigley, 1994), pollen sterility (Saini et al., 1981), tissue dehydration, lower carbon assimilation, depletion of carbohydrate reserve, acceleration of plant growth (Fischer, 1980; Kase et al., 1984) and reduction of plant photosynthetic capacity (Harding et al., 1990) . So, development of heat stress tolerant wheat genotypes based on physiological approaches to minimize the above mention heat-induced effects might be the best way to cope with heat stress problem. There are some physiological traits used as selection criteria for heat tolerance in wheat, and have strong correlation with grain yield under heat stress. viz. membrane thermostability (Sharma et al., 2016; Yildirim et al., 2009; Reynolds et al., 1994), canopy temperature depression (Bahar et al., 2008; Reynolds et al., 1994, 2001), chlorophyll content (Yildirim et al. 2011), stomatal conductance (Reynolds et al. 1994), grain number per spike, grains per spikelet and thousand grain weight and grain yield (Pimentel et al., 2015). The main objective of this study was to evaluate some exotic wheat genotypes to identify heat tolerant genotypes for using in future breeding program and to prepare a ranking table on the basis of physiological traits to identify the best genotype. 


\section{Materials and Methods}

Experiment was conducted with 18 wheat genotypes among them 14 were exotic (designated as HO18 to HO31; collected from International Maize and Wheat Improvement Center [CIMMYT], Mexico) and 4 were popular genotypes (Shourav, Gourab, Shatabdi, Sonalika, collected from BAU germplasm) in 2014-15 at Field Experimental Laboratory, Dept. of Genetics and Plant Breeding, Bangladesh Agricultural University, Mymensingh. Experiment was conducted with three replications and two treatments in a Randomized Completely Block Design (RCBD). Optimum time sowing (15 November, 2014) considered as first treatment and late sowing by one month (15 December, 2014) for imposing heat stress was second treatment. Range of maximum, minimum and mean temperature during the experiment were presented in Fig. 1. Data on physiological traits such as canopy temperature depression, leaf chlorophyll content, membrane thermostability and some other yield contributing characters such as number of spikelets per spike, no. of grains per spike, 200-grain weight and yield per plant (g) were recorded on the basis of following procedures as indicated below. The recorded data on different parameters were analyzed by using MINITAB version 17.0, MSTAT-C and MS Excel ${ }^{\circledR} 2007$.

According to Pietragalla (2012), infra-red thermometer (Model: CEM DT8818) was used to record the canopy temperature depression (CTD) at 89 DAS in both treatments during which control treatment was in $27^{\circ} \mathrm{C}$ and $2^{\text {nd }}$ treatment had $29^{\circ} \mathrm{C}$ day temperature at noon. Leaf chlorophyll content at anthesis (GS65) was measured with a SPAD meter (Minolta-502) from five flag leaves of each genotype in a replication in CCI (chlorophyll concentration index) between 12.00-14.00 $\mathrm{h}$ of in fine windless and cloudless days. Membrane thermostability was measured by following the guideline of Yildirim et al. (2009) from eight fully expanded leaves of each genotype, collected from randomly selected plants of each replication. The percentage of solute leakage was estimated by using the following equation-

$$
\begin{aligned}
& \text { So, Leaf Membrane Thermostability (MTS\%) }= \\
& \left\{1-\frac{T_{1}}{T_{2}}\right\} \times 100
\end{aligned}
$$

Where, $\mathrm{T}$ refer to electrical conductivity of heat treated samples, and the subscript 1 and 2 refer to electric conductivity readings before and after boiling for $1 \mathrm{hr}$, respectively.

Number of spikelet's per spike, no. of grains per spike, 200-kernels weight (g), grain yield (g) were measured as per description of Pietragalla and Pask (2012).

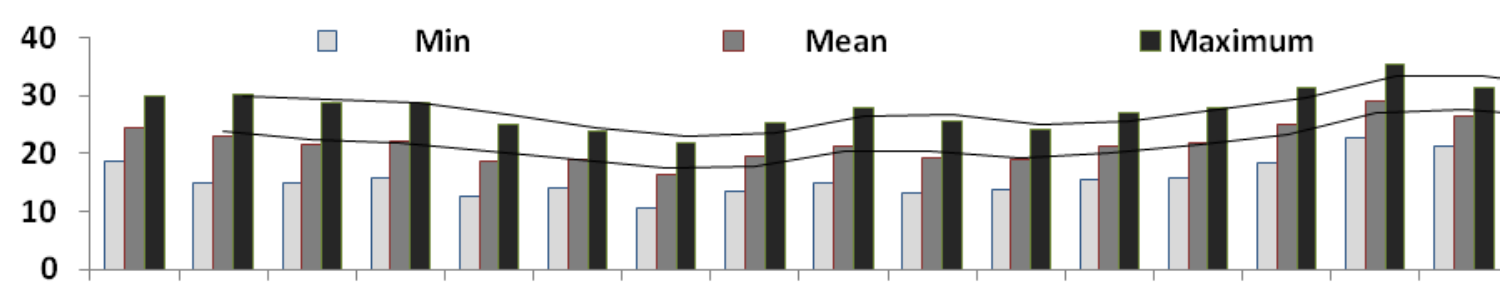

1-10 11-20 21-30 1-10 11-20 21-30 1-10 11-20 21-30 1-10 11-20 21-28 1-10 11-20 21-30 1-10 Nov. Nov. Nov. Dec. Dec. Dec. Jan. Jan. Jan. Feb. Feb. Feb. Mar. Mar. Mar. Apr.

Fig. 1. Bar graph shows the average min., mean and max. temperature $\left({ }^{\circ} \mathrm{C}\right)$ of every 10 days from 01 November, 2014 to 10 April, 2015 (Experimental period). Data collected from weather division of BAU, Mymensingh. Here, $\mathrm{Y}=$ indicates temperature $\left({ }^{\circ} \mathrm{C}\right), \mathrm{X}=$ indicates days

\section{Results and Discussion}

Analysis of variance (Table 1) showed that, for canopy temperature depression (CTD) there was no significant variation among the genotypes and genotype-treatment interaction does not have any effects on the genotypes. The results obtained from ANOVA table for the trait of leaf chlorophyll content, no. of grains per spike, 200grain weight, grain yield per plant revealed that highly significant differences existed between genotypes and treatments. These results indicate that genotypes responded differently to the heat stressed conditions. Even, genotype-treatment interaction has significant effect on each genotype except grain yield trait. On the other hand, performance of membrane thermostability and no. of spikelets per spike on genotype was almost similar in different environmental growing condition and the effect of genotype-treatment interaction on genotypes has no differences. But, these two traits performance was different on different genotypes. 
Table 1. ANOVA for 7 plant characters of 18 wheat genotypes grown under heat stress condition

\begin{tabular}{|c|c|c|c|c|c|}
\hline \multirow[b]{2}{*}{$\begin{array}{l}\text { SL. } \\
\text { No. }\end{array}$} & \multirow[b]{2}{*}{ Traits } & \multicolumn{4}{|c|}{ Mean Square } \\
\hline & & $\begin{array}{c}\text { Genotype } \\
\text { d.f. }\end{array}$ & $\begin{array}{l}\text { Treatment } \\
\text { d.f. }\end{array}$ & $\begin{array}{c}\text { Gen.* Treat. } \\
\text { d.f. }\end{array}$ & Error \\
\hline 1. & Canopy temp. depression ( C) (CTD) & $2.874^{\mathrm{NS}}$ & $358.978 * *$ & $2.061^{\mathrm{NS}}$ & 2.852 \\
\hline 2. & Leaf chlorophyll content ( $\mathrm{LChl})$ & $241.805 * *$ & $1050.941 * *$ & $39.525 *$ & 22.436 \\
\hline 3. & Membrane thermostability (\%) (MT) & $211.347 * *$ & $7.938^{\mathrm{NS}}$ & $48.378^{\mathrm{NS}}$ & 53.668 \\
\hline 4. & No. of spikelets per spike (Nspk) & $17.162 * *$ & $0.231^{\mathrm{NS}}$ & $2.173^{\mathrm{NS}}$ & 1.311 \\
\hline 5. & No. of grains per spike (Grspk) & $193.109 * *$ & $472.926 * *$ & $120.593 *$ & 62.851 \\
\hline 6. & 200-grain weight (200grwt) & $2.136 * *$ & $94.678 * *$ & $1.552 * *$ & 0.562 \\
\hline 7. & Yield per plant (g) [Yd] & $214.401 * *$ & $1409.561 * *$ & $98.413^{\mathrm{NS}}$ & 85.72 \\
\hline
\end{tabular}

Legend, * indicates $5 \%$ level of significance; ** indicates $1 \%$ level of significance; ${ }^{\mathbf{N S}}$ indicates non-significance

Different mean performances were shown by different varieties for the traits studied (Table 2). Mean of canopy temperature ranged from $24.62^{\circ} \mathrm{C}$ (H029) to $21.83^{\circ} \mathrm{C}$ (H018) with an average of $23.414^{\circ} \mathrm{C}$. It has been found, in heat tolerant genotypes, leaf stomatal conductance and leaf transpiration rates increased with the increase of temperature (Anjum et al., 2008). These activities help plants to keep cooler canopy to avoid heat stress (Anjum et al., 2008). Cooler CTD helps to improve the assimilation rate and yield in stress condition (Kottmann et al., 2013; Sharma et al., 2016). Almost similar relationship was found in the Figure 2, where, it is clear that with the increase of CTD of genotype grain yield was reduced. But, H022 genotype showed considerable increase of yield with the increasing temperature. Besides, genotypes H018, H019, H024, H026 and H026 which were placed in Group-1 can maintain cooler canopy and gives higher yield.

Table 2. Mean value of 18 wheat genotypes for 7 traits studied in the experiment

\begin{tabular}{|c|c|c|c|c|c|c|c|c|}
\hline S1. No. & Genotype & CTD & LChl & MT & Nspk & Grspk & 200 grwt & $\mathrm{Yd}(\mathrm{g})$ \\
\hline 1 & $\mathrm{HO} 18$ & $21.83 \mathrm{~b}$ & $52.27 \mathrm{a}$ & $24.06 \mathrm{a}-\mathrm{d}$ & $19.17 \mathrm{a}$ & $30.0 \mathrm{abc}$ & $7.043 \mathrm{~d}$ & $23.41 \mathrm{abc}$ \\
\hline 2 & HO19 & $23.02 \mathrm{ab}$ & $49.07 \mathrm{ab}$ & $23.62 \mathrm{a}-\mathrm{d}$ & $17.67 \mathrm{a}-\mathrm{e}$ & $28.50 \mathrm{abc}$ & $7.598 \mathrm{~cd}$ & $21.64 \mathrm{abc}$ \\
\hline 3 & $\mathrm{HO} 20$ & $23.70 \mathrm{ab}$ & $41.25 \mathrm{c}-\mathrm{f}$ & $14.45 \mathrm{~d}$ & $17.0 \mathrm{cde}$ & $38.83 \mathrm{a}$ & $8.113 \mathrm{bcd}$ & $24.37 \mathrm{abc}$ \\
\hline 4 & $\mathrm{HO} 21$ & $23.85 \mathrm{ab}$ & $48.42 \mathrm{abc}$ & $34.17 \mathrm{a}$ & $16.8 \mathrm{cde}$ & 29.0 abc & $8.032 \mathrm{bcd}$ & $21.79 \mathrm{abc}$ \\
\hline 5 & $\mathrm{HO} 22$ & $24.32 \mathrm{ab}$ & $44.02 \mathrm{~b}-\mathrm{e}$ & $23.19 \mathrm{a}-\mathrm{d}$ & $17.67 \mathrm{a}-\mathrm{e}$ & $38.17 \mathrm{a}$ & $8.392 \mathrm{bc}$ & $33.37 \mathrm{a}$ \\
\hline 6 & $\mathrm{HO} 23$ & $23.45 \mathrm{ab}$ & $50.27 \mathrm{ab}$ & $18.43 \mathrm{~cd}$ & $19.00 \mathrm{ab}$ & $20.17 \mathrm{c}$ & $7.77 \mathrm{bcd}$ & $28.84 \mathrm{ab}$ \\
\hline 7 & $\mathrm{HO} 24$ & $22.67 \mathrm{ab}$ & $50.78 \mathrm{ab}$ & $25.47 \mathrm{a}-\mathrm{d}$ & $18.00 \mathrm{a}-\mathrm{d}$ & $33.17 \mathrm{ab}$ & $7.603 \mathrm{~cd}$ & $29.05 \mathrm{ab}$ \\
\hline 8 & $\mathrm{HO} 25$ & $23.08 \mathrm{ab}$ & $53.08 \mathrm{a}$ & $26.38 \mathrm{abc}$ & $16.17 \mathrm{def}$ & $24.50 \mathrm{bc}$ & $7.74 \mathrm{bcd}$ & $16.64 \mathrm{bc}$ \\
\hline 9 & $\mathrm{HO} 26$ & $22.92 \mathrm{ab}$ & $43.93 \mathrm{~b}-\mathrm{e}$ & $16.28 \mathrm{~cd}$ & $19.00 \mathrm{ab}$ & $23.67 \mathrm{bc}$ & $8.872 \mathrm{ab}$ & $21.05 \mathrm{abc}$ \\
\hline 10 & $\mathrm{HO} 27$ & $22.57 \mathrm{ab}$ & $51.00 \mathrm{ab}$ & $21.00 \mathrm{bcd}$ & $18.5 \mathrm{abc}$ & $24.00 \mathrm{bc}$ & $8.425 \mathrm{bc}$ & $24.10 \mathrm{abc}$ \\
\hline 11 & $\mathrm{HO} 28$ & $23.07 \mathrm{ab}$ & $47.43 \mathrm{a}-\mathrm{d}$ & $17.57 \mathrm{~cd}$ & $16.83 \mathrm{cde}$ & $21.00 \mathrm{bc}$ & $8.330 \mathrm{bc}$ & $15.29 \mathrm{bc}$ \\
\hline 12 & $\mathrm{HO} 29$ & $24.62 \mathrm{a}$ & $36.97 \mathrm{ef}$ & $27.28 \mathrm{abc}$ & $16.67 \mathrm{cde}$ & $25.00 \mathrm{bc}$ & $8.383 \mathrm{bc}$ & $18.74 \mathrm{abc}$ \\
\hline 13 & HO30 & $23.30 \mathrm{ab}$ & $48.68 \mathrm{abc}$ & $18.52 \mathrm{~cd}$ & $17.33 \mathrm{a}-\mathrm{e}$ & $24.67 \mathrm{bc}$ & $8.2 \mathrm{bcd}$ & $20.03 \mathrm{abc}$ \\
\hline 14 & HO31 & $23.78 \mathrm{ab}$ & 40.62 def & $32.22 \mathrm{ab}$ & $15.83 \mathrm{efg}$ & $26.50 \mathrm{abc}$ & $7.75 \mathrm{bcd}$ & $18.73 \mathrm{abc}$ \\
\hline 15 & Shourav & $24.30 \mathrm{ab}$ & 36.68 ef & $33.04 \mathrm{a}$ & $14.33 \mathrm{fgh}$ & $21.17 \mathrm{bc}$ & $8.437 \mathrm{bc}$ & $12.12 \mathrm{c}$ \\
\hline 16 & Gourab & $23.87 \mathrm{ab}$ & $34.68 \mathrm{f}$ & $27.77 \mathrm{abc}$ & $13.33 \mathrm{~h}$ & $18.67 \mathrm{c}$ & $7.678 \mathrm{bcd}$ & $9.41 \mathrm{c}$ \\
\hline 17 & Shatabdi & $23.47 \mathrm{ab}$ & $36.15 \mathrm{f}$ & $27.94 \mathrm{abc}$ & $17.17 \mathrm{~b}-\mathrm{e}$ & $28.17 \mathrm{abc}$ & $8.262 \mathrm{bcd}$ & $17.98 \mathrm{bc}$ \\
\hline 18 & Sonalika & $23.65 \mathrm{ab}$ & $36.52 \mathrm{ef}$ & $18.07 \mathrm{~cd}$ & $14.00 \mathrm{gh}$ & $24.17 \mathrm{bc}$ & $9.790 \mathrm{a}$ & $16.96 \mathrm{bc}$ \\
\hline $\mathrm{CV}(\%)$ & & 7.21 & 10.63 & 30.71 & 6.77 & 29.77 & 9.22 & 44.62 \\
\hline Maximum & & 24.62 & 53.08 & 34.17 & 19.17 & 38.83 & 9.790 & 33.37 \\
\hline Minimum & & 21.83 & 34.68 & 14.45 & 13.33 & 18.67 & 7.04 & 9.41 \\
\hline Mean & & 23.414 & 44.545 & 23.858 & 16.91 & 26.63 & 8.13 & 20.75 \\
\hline Lsd (0.05) & & 2.750 & 7.713 & 11.93 & 1.865 & 12.91 & 1.221 & 15.08 \\
\hline
\end{tabular}

Legends,

CTD = Canopy temp. depression, Leaf chlorophyll content (LChl), MT= Membrane thermostability $(\%)$, Nspk = No. of spikelets per spike, Grspk = No. of grains per spike, 200grwt $=200$-grain weight, Yd $=$ Yield per plant $(\mathrm{g})$

Leaf chlorophyll content (Lchl) is another important trait because it helps to improve the grain yield and maturity even when heat stress was imposed (Kumar et al., 2010). Wittenbach (1979) reported that, loss of chlorophyll coincides with the development of grain filling. So, improved photosynthesis comes from higher leaf chlorophyll content, which is a major objective for improving the yield potential of wheat (Waddington et al., 1987). Leaf chlorophyll content of the flag leaf varied from 34.68 (Gourab) to 53.08 (HO25) with a mean of 44.545 CCI. Fig. 2 and 3 also depicted the similar findings, where genotypes with lower leaf chlorophyll content give lower grain yield, but higher chlorophyll content brings higher grain yield. Interestingly, Sonalika demonstrated highest 200-grain weight even in lower leaf chlorophyll content and provides higher yield than any other local varieties used in this experiment. In contrast, H022 gave the highest grain yield though has moderate leaf chlorophyll content. 
In heat stress condition, membrane thermostability is an important mechanism and measured to determine the adaptation ability of cell. Levitt (1972) reported that, cell membrane is the primary physiological injury site by heat. Because, when heat stress imposed on the cell membrane a series of consequences occurred such as acceleration of the kinetic energy, loosening of chemical bonds within molecules, denaturation of proteins, increasing the unsaturated fatty acids and the amount of fluid lipid bilayer (Savchenko et al., 2002). Such types of changes enhance the permeability of membranes, increased the loss of electrolytes and decreased cell membrane thermostability. Membrane thermostability was measured based on the estimation of solute leakage from tissue under heat stress condition. So, the best genotypes leaked out lowest amount of solute from the leaf in stress condition. Sharma et al. (2016) reported positive correlation between membrane thermostability and grain yield in heat grown under heat stress. Membrane thermostability had an average of $23.858 \%$, with a range of $14.45 \%$ (HO20) to $34.17 \%$ (HO21). The lowest relative injury percentage of membrane was showed by HO21 and Shourav i.e. $34.17 \%$ and $33.04 \%$, respectively. From Fig. 4 it is evident that genotypes with lower membrane membrane thermostability gave lower yield. However, genotypes with lower thermostability also demonstrated higher yield (H022) indicating plants ability to escape the heat stress by early flowering and higher yield potential. In contrast, several genotypes, mostly local genotypes (viz. Gourab, Shourav) showed poor yield performance in spite of having higher membrane thermostability, indicating lower yield potential of those genotypes (see Group 4, Fig. 4).
Heat stress has negative effect on the plant growth, development and productivity (Hassan and Raffi, 2017; Pimentel et al., 2015). Genotypes showed variation for the trait of no. of spikelet per spike from 13.33 (Gourab) to 19.17 (HO18) with a mean of 16.91 . HO18 genotype was the best genotype for this trait than followed by HO23 (19.00), HO26 (19.00), HO27 (18.50), HO24 (18.00), HO19 (17.67), HO22 (17.67) and HO30 (17.33) genotypes. The number of grain per spike ranged from 18.67 (Gourab) to 38.83 (HO20) with a mean of 26.63 grains per spike. So, HO20 produced largest number of grains but Gourab had lowest number of grain per spike. Heat stress during grain-filling stage inhibits translocation of photosynthates to the developing grains and starch synthesis within the grains, ultimately which lowers grain weight (Bhullar et al., 1985, Mohammadi et al., 2004). The range of 200-grain weight from $9.790 \mathrm{gm}$ (Sonalika) to $7.043 \mathrm{gm}$ (HO18) and the average weight was $8.135 \mathrm{gm}$ whereas grain yield had a range of 33.37 gm (H022) to $9.41 \mathrm{gm}$ (Gourab), averaging $20.75 \mathrm{gm}$ yield for five plants. The 200-grain weight was highest in Sonalika (9.790 gm) which was followed by $\mathrm{HO} 26$ (8.872 gm).

Furthermore, a ranking table (Table 3) for 18 wheat genotypes was made on the basis of mean performances of traits studied. Based on the score, genotypes were arranged from best performer to inferior performer. According to the table best genotype was $\mathrm{H} 024$ and inferior was Gourab.

Table 3. Ranking of 18 wheat genotypes for 7 traits under heat stress

\begin{tabular}{|c|c|c|c|c|c|c|c|c|c|}
\hline Genotype & CTD & LChl & MT & Nspk & Grspk & 200grwt & Yield & Total & Ranking \\
\hline HO18 & 2.0 & 6.0 & 2.5 & 8.0 & 2.0 & 1.0 & 7.5 & 29.0 & 3 \\
\hline HO19 & 1.5 & 5.5 & 2.5 & 6.0 & 2.0 & 1.5 & 6.5 & 25.5 & 6 \\
\hline $\mathrm{HO} 20$ & 1.5 & 2.5 & 1.0 & 5.0 & 3.0 & 2.0 & 9.0 & 24.0 & 8 \\
\hline $\mathrm{HO} 21$ & 1.5 & 5.0 & 4.0 & 5.0 & 2.0 & 2.0 & 7.0 & 26.5 & 5 \\
\hline $\mathrm{HO} 22$ & 1.5 & 3.5 & 2.5 & 6.0 & 3.0 & 2.5 & 11.0 & 30.0 & 2 \\
\hline $\mathrm{HO} 23$ & 1.5 & 5.5 & 1.5 & 7.5 & 1.0 & 2.0 & 10.0 & 29.0 & 3 \\
\hline $\mathrm{HO} 24$ & 1.5 & 5.5 & 2.5 & 6.5 & 2.5 & 1.5 & 10.5 & 30.5 & 1 \\
\hline $\mathrm{HO} 25$ & 1.5 & 6.0 & 3.0 & 4.0 & 1.5 & 2.0 & 3.0 & 21.0 & 10 \\
\hline $\mathrm{HO} 26$ & 1.5 & 3.5 & 1.5 & 7.5 & 1.5 & 3.5 & 6.0 & 25.0 & 7 \\
\hline $\mathrm{HO} 27$ & 1.5 & 5.5 & 2.0 & 7.0 & 1.5 & 2.5 & 8.5 & 28.5 & 4 \\
\hline $\mathrm{HO} 28$ & 1.5 & 4.5 & 1.5 & 5.0 & 1.5 & 2.5 & 2.5 & 19.0 & 12 \\
\hline HO29 & 1.0 & 1.5 & 3.0 & 5.0 & 1.5 & 2.5 & 5.0 & 19.5 & 11 \\
\hline $\mathrm{HO} 30$ & 1.5 & 5.0 & 1.5 & 6.0 & 1.5 & 2.0 & 5.5 & 23.0 & 9 \\
\hline HO31 & 1.5 & 2.0 & 3.5 & 3.0 & 2.0 & 2.0 & 5.0 & 19.0 & 12 \\
\hline Shourav & 1.5 & 1.5 & 4.0 & 2.0 & 1.5 & 2.5 & 1.5 & 14.5 & 14 \\
\hline Gourab & 1.5 & 1.0 & 3.0 & 1.0 & 1.0 & 2.0 & 1.0 & 10.5 & 15 \\
\hline Shatabdi & 1.5 & 1.0 & 3.0 & 5.5 & 2.0 & 2.0 & 4.5 & 19.5 & 11 \\
\hline Sonalika & 1.5 & 1.5 & 1.5 & 1.5 & 1.5 & 4.0 & 4.0 & 15.5 & 13 \\
\hline
\end{tabular}

Legend, Canopy temperature depression $=$ CTD; Leaf chlorophyll content $=$ LChl; Membrane thermostbility = MTS; No. of spikelets per spike $=$ Nspk; No. of grains per spike $=$ Grspk; 200-grain weight $=200$ grwt; Yield per plant $(\mathrm{g})=\mathrm{Yd}$

*Rating Pattern, Best genotype scored with highest grade for individual trait performance and ranked based on cumulative score. 


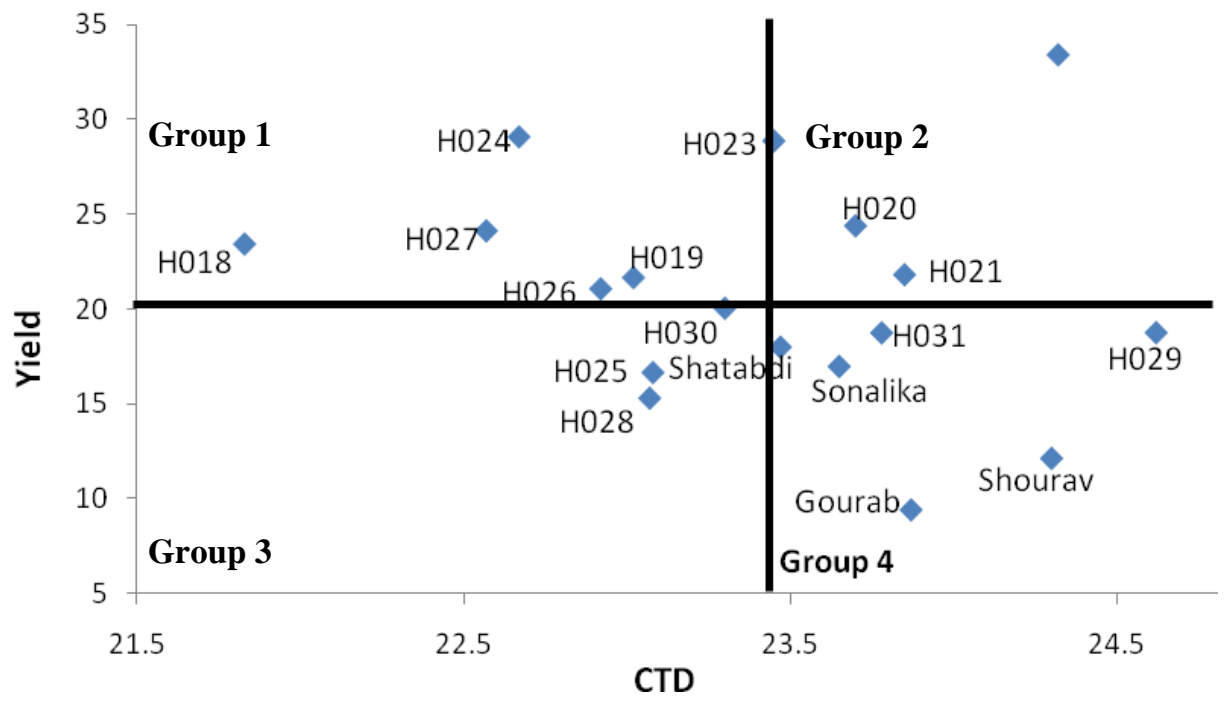

Fig. 2. Performances of 18 wheat genotypes in scatter plot based on of canopy temperature depression and yield

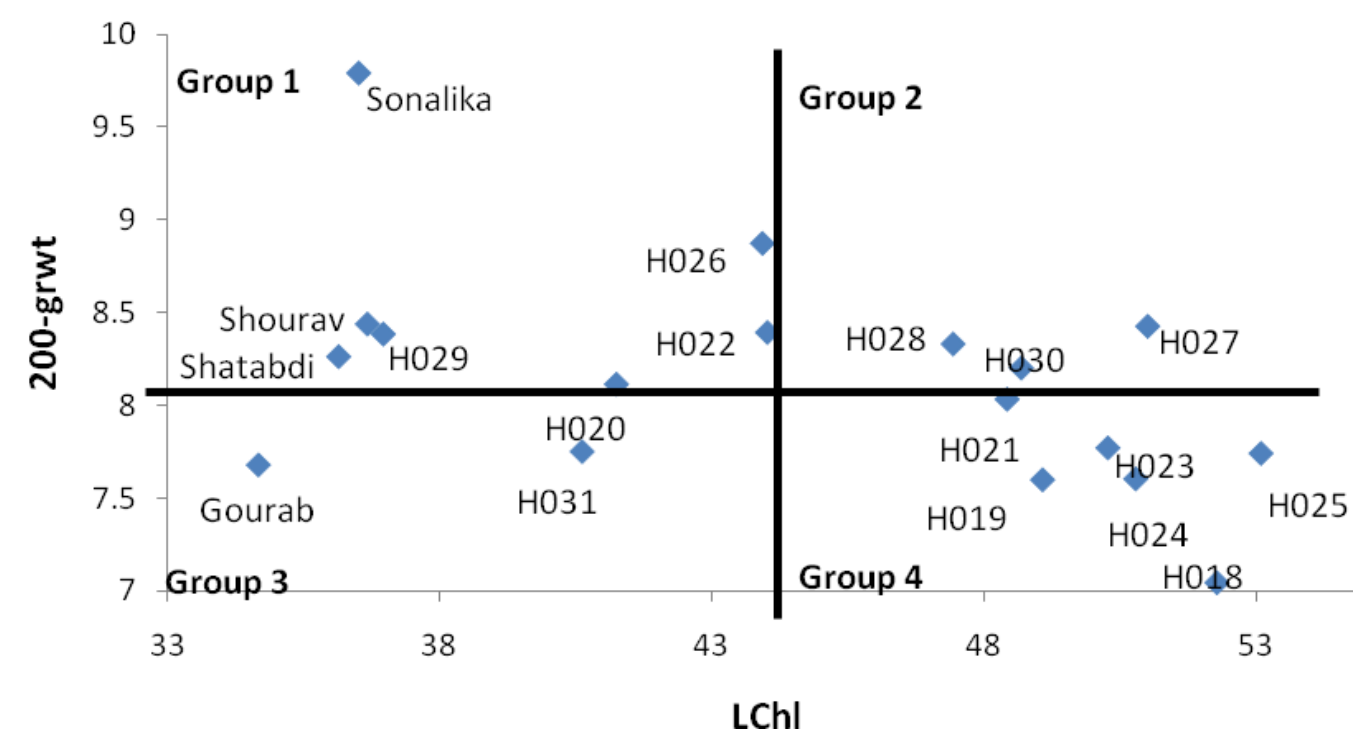

Fig. 3. Performances of 18 wheat genotypes in scatter plot based on of leaf chlorophyll content and 200-grain weight

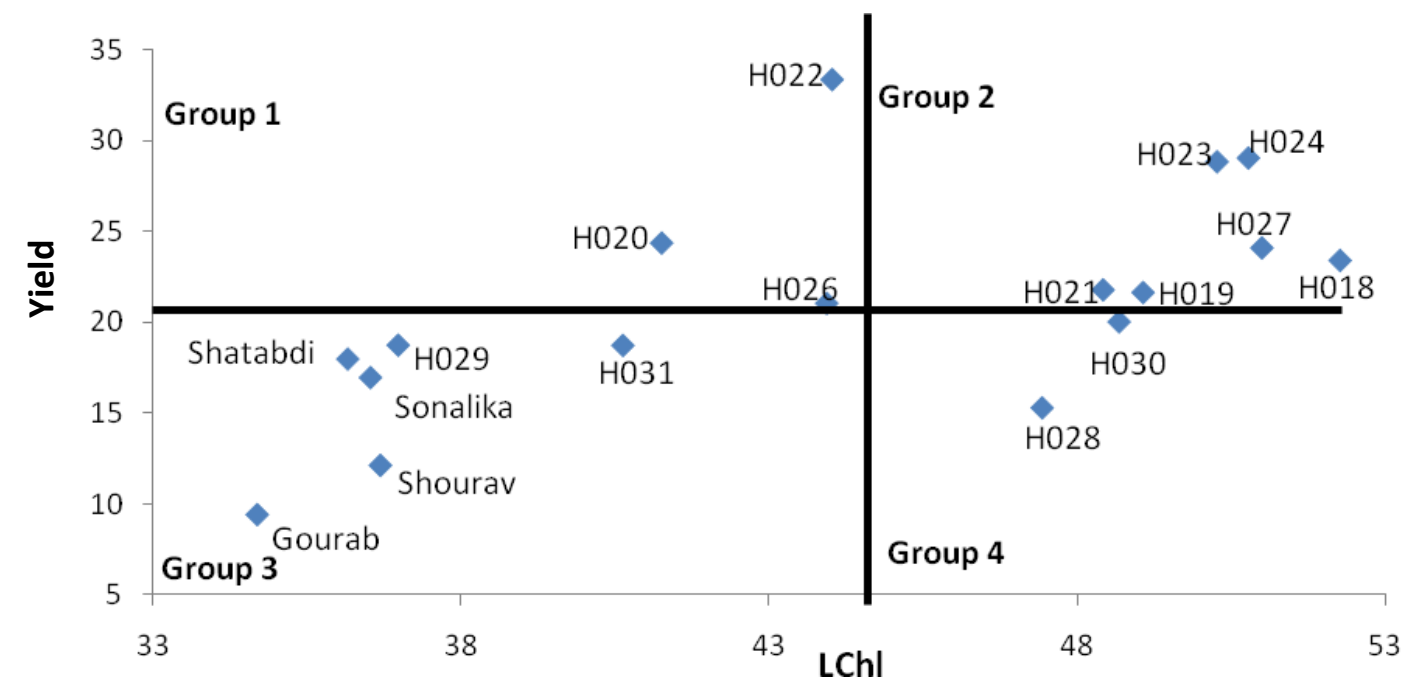

Fig. 4. Performances of 18 wheat genotypes in scatter plot based on of leaf chlorophyll content and yield 


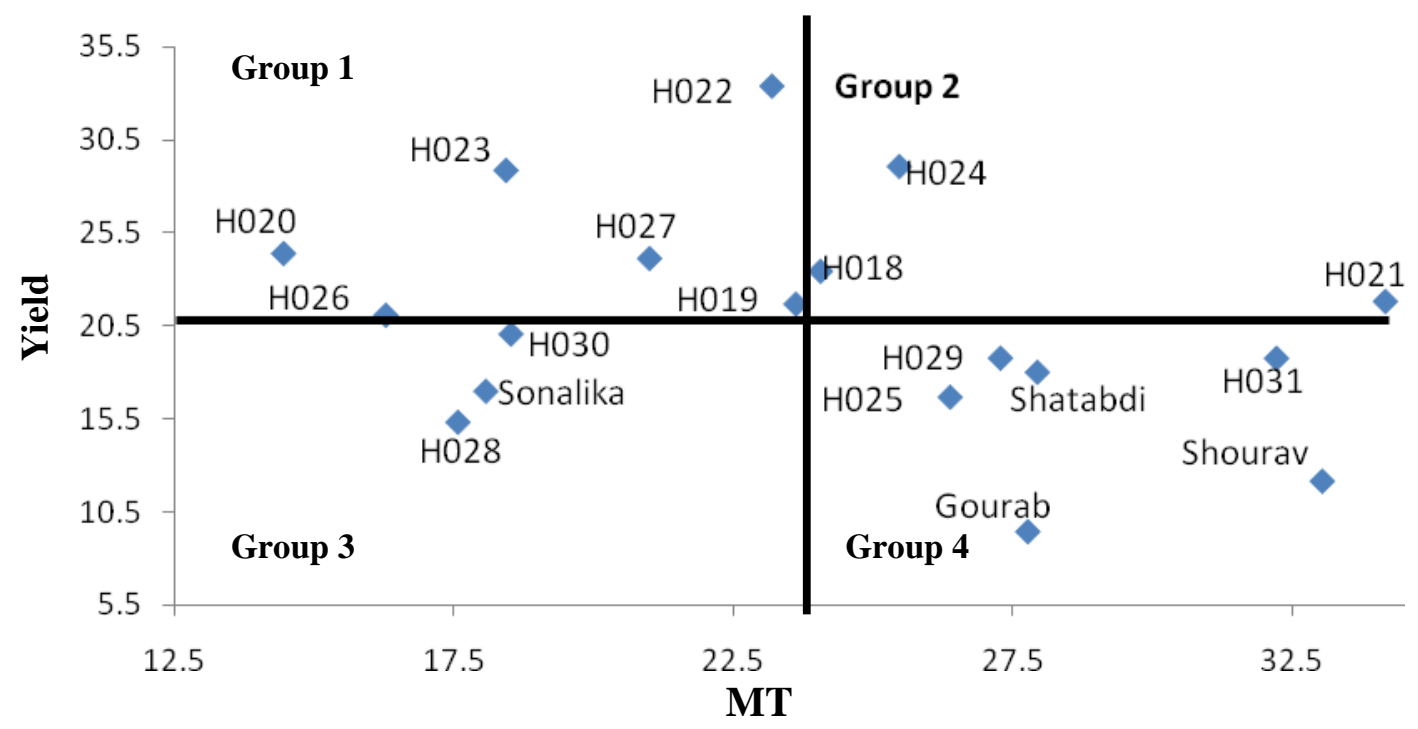

Fig. 5. Performances of 18 wheat genotypes in scatter plot based on of membrane thermostability and yield

\section{Conclusion}

Heat tolerance in wheat has been in the prime research priority in wheat growing areas considering global warming and changing cropping pattern. Therefore, wheat genotypes with different heat tolerance traits have great importance in developing heat tolerant wheat varieties. The present study identified several genotypes with different gradients of heat tolerant traits. These genotypes may be used for future breeding program for heat tolerant variety development to mitigate the heat stress problem for increased wheat production.

\section{Acknowledgements}

This research was conducted under a research project funded by Bangladesh Agricultural University Research System (Project no. 2013/40/AU-GC). The authors expressed cordial thanks to International Maize and Wheat Improvement Center (CIMMYT) for providing the exotic genotypes from their germplasm.

\section{References}

Anjum, F., Wahid, A., Javed, F. and Arshad, M. 2008. Influence of foliar applied thiourea on flag leaf gas exchange and yield parameters of bread wheat (Triticum aestivum L.) cultivars under salinity and heat stress. International Journal of Agriculture and Biology. 10: 619-626.

Bahar, B., Yildirim, M., Barutcular, C. and Genc, I. 2008. Effect of canopy temperature depression on grain yield and yield components in bread and durum wheat. Notulae Botanicae Horti Agrobotanici Cluj-napoca, 36: 34-37.

Bahar, B., Yildrim, M. and Yucel, C. 2011. Heat and drought resistance criteria in spring bread wheat (Triticum aestivum L.): Morphophysiological parameters for heat tolerance. Scientific Research and Essays, 6: 2212-2220. https://doi.org/10.5897/SRE11.418

Bhullar, S. S., Jenner, C. F. 1985. Differential responses to high temperature of starch and nitrogen accumulation in the grain of four cultivars of wheat. Australian Journal of Plant Physiology, 12: 363-375.

FAO. 2013. Food and agricultural organization of the United Nations, FAO Statistical Yearbook 2013: World food and agriculture. FAO, Rome. pp. 289.
Fischer, R. A. 1980. Influence of water stress on crop yield in semiarid regions. In: NC Turner and PJ Kramer (Editors), Adaptation of plants to water and high temperature stress. Wiley, New York, pp. 323-339.

Fischer, R. A. 1985. Physiological limitations to producing wheat in semi-tropical and tropical environments and possible selection criteria. In: Wheats for more tropical environments: A proceeding of the international symposium, 24-28 Sept., 1984, Mexico DF, CIMMYT, pp. 209-230.

Haque, M. Z., Hasan, M. M., Rajib, M. M. R. and Hasan, M. M. 2009. Identification of cultivable heat tolerant wheat genotypes suitable for Patuakhali district in Bangladesh. Journal of Bangladesh Agricultural University, 7(2): 241-246.

Harding, S. A., Guikema, J. A. and Paulsen, G. M. 1990. Photosynthetic decline from high temperature stress during maturation of wheat I. Interaction with senescence process. Plant Physiology, 92: 648-653. https://doi.org/10.1104/pp.92.3.648 PMid:16667329 PMCid:PMC1062348

Hassan, M. M. and Rafi, S. A. 2017. Genetic analysis of heat tolerance in wheat (Triticum aestivum L.). In: Proceedings on 10th Biennial Conference of Plant Breeding and Genetic Society of Bangladesh, BARC Auditorium, Dhaka, 07 to 08 January, 2017, pp. 48-49.

IPCC. 2013. Inter-governmental Panel on Climate Change, Climate Change 2013: The physical science basis. Contribution of working group I to the Fifth assessment report of the intergovernmental panel on climate change. Cambridge university press, Cambridge, UK and New York, NY, USA.

Karmakar, S. and Shrestha, M. L. 2000. Recent Climatic Changes in Bangladesh. SAARC Meteorological Research Centre, Agargaon, Dhaka, Bangladesh.

Kase, M. and Catsky, J. 1984. Maintenance and growth components of dark respiration rate in leaves of $\mathrm{C} 3$ and $\mathrm{C} 4$ plants as affected by leaf temperature. Biologia Plantarum, 26: 461-470. https://doi.org/10.1007/BF02909600

Kotmann, L., Schittenhelm, S., Wittich, K. P., and Wilde, P. 2013. Suitability of canopy temperature depression in a temperature climate with drought -stressed winter rye, determined with three infrared measurement devices. Journal of Agronomy and Crop Science, 199: 385-394. https://doi.org/10.1111/jac.12035

Kumar, U., Joshi, A. K., Kumari, M., Paliwal, R., Kumar, S. and Röder, M. S. 2010. Identification of QTLs for stay green trait in wheat (Triticum aestivum L.) in the 'Chirya 3' $\times$ 'Sonalika' population. Euphytica, 174:437-445. 
https://doi.org/10.1007/s10681-010-0155-6

Levitt, J. 1972. Responses of plants to environmental stresses. Academic Press, NY. pp. 698.

Mohammadi, V., Qannadha, M. R., Zali, A. A. and Yazdi-Samadi, B. 2004. Effect of post-anthesis stress on head traits of wheat. International Journal of Agricultural Biology, 6:42-44.

Paulsen, G. M. 1994. High temperature response of crop plants. In: Physiology and determination of Crop Yield ASACCSASSSA. Madison, WI. pp. 365-389.

Pietragalla, J. 2012. Canopy temperature. In: Physiological Breeding II: A field guide to wheat phenotyping by Pask, A.J.D., Pietragalla, J., Mullan, D.M. and Reynolds, M.P. (Eds), CIMMYT, Mexico, pp. 10-14.

Pietragalla, J. and Pask, A. 2012. Grain yield and yield components. In: Physiological Breeding II: A field guide to wheat phenotyping by Pask, A.J.D., Pietragalla, J., Mullan, D.M and Reynolds, M.P. (Eds), CIMMYT, Mexico, pp. 95-105.

Pimentel, A. J. B., Rocha, J. R. do A. S. de C., de Souza, M. A., Ribeiro, G., Silva, C. R. and Oliveira, I. C. M. 2015. Characterization of heat tolerance in wheat cultivars and effects on production components. Revista Ceres, 62(2):191-198 https://doi.org/10.1590/0034-737X201562020009

Rane, J., Pannu, R. K., Sohu, V. S., Saini, R. S., Mishra, B., Shoran, J., Crossa, J., Vargas, M. and Joshi, A. K. 2007. Performance of yield and stability of advanced wheat genotypes under heat stressed environments of Indo-Gangetic Plains. Crop Science, 47: 1561-1573. https://doi.org/10.2135/cropsci2006.07.0479

Reynolds, M. P., Balota, M., Delgado, M. I. B., Amani, I. and Fischer, R. A. 1994. Physiological and morphological traits associated with spring wheat yield under hot, irrigated conditions. Australian Journal of Plant Physiology, 21: 717-730.

Reynolds, M. P., Nagarajan, S., Razzaque, M. A. and Ageeb, O. A. A. 2001. Heat tolerance. In: Reynolds, M.P., Monasterio, J.I.O. and McNab, A. (Editors), Application of physiology in wheat breeding. CIMMYT, Mexico. pp.124-135.

Reynolds, M. P., Singh, R. P., Ibrahim, A., Ageeb, O. A., LarquéSaavedra, A. and Quick, J. S. 1998. Evaluating physiological traits to compliment empirical selection for wheat in warm environments. Euphytica, 100: 85-94. https://doi.org/10.1023/A:1018355906553

Saini, H. S., and Aspinall, D. 1981. Effect of water deficit on sporogenesis in wheat (Triticum aestivum L.). Annals of Botany, 48: 623-633. https://doi.org/10.1093/oxfordjournals.aob.a086170

Savchenko, G.E., Klyuchareva, E.A., Abramchik, L.M. and Serdyuchenko, E.V. 2002. Effect of periodic heat shock on the inner membrane sustem of etioplasts. Russian Journal of Plant Physiology, 49: 349-359. https://doi.org/10.1023/A:1015592902659
Sharma, P., Sareen, S. Saini, M. and Shefali. 2016. Assessing genetic variation for heat stress tolerance in Indian bread wheat genotypes using morpho-physiological traits and molecular markers. Plant Genetic Resources, 1-9. https://doi.org/10.1017/S1479262116000241

Sikder, S. and Paul, N. K. 2010. Effect of post-anthesis heat stress on stem reserves mobilization, canopy temperature depression and floret sterility of wheat cultivars. Bangladesh Journal of Botany, 39: 51-55. https://doi.org/10.3329/bjb.v39i1.5526

Stone, P. 2001. The effects of heat stress on cereal yield and quality hexaploid wheat. Euphytica, 126: 275-282.

Stone, P. J. and Nicolas, M. E. 1994. Wheat cultivars vary widely in their responses of grain yield and quality to short periods of post-anthesis heat stress. Australian Journal of Plant Physiology, 21: 887-900.

Waddington, S. R., Osmanzi, M., Yoshida, M. and Ransom, J. K. 1987. The yield of durum wheat released in Mexico between 1960 and 1984. Journal of Agricultural Science, Cambridge, 108: 469-477. https://doi.org/10.1017/S002185960007951X

Wahid, A., Gelani, S., Ashraf, M. and Foolad, M. R. 2007. Heat tolerance in plants: An overview. Australian Journal of Plant Physiology, 21: 695-703.

Wardlaw, I. F. and Wrigley, C. W. 1994. Heat tolerance in temperate cereals: An overview. Australian Journal of Plant Physiology, 21: 695-703.

Wardlaw, I. F., Dawson, I. A. and Munibi, P. 1989. The tolerance of wheat to high temperature during reproductive growth: II. Grain development. Australian Journal of Agricultural Research. 40: 15-24. https://doi.org/10.1071/AR9890015

Wittenbach, V. A. 1979. Ribulose biophosphate carboxylase and proteolytic activity in wheat leaves from anthesis through senescence. Plant Physiology, 64: 884-887. https://doi.org/10.1104/pp.64.5.884 PMid:16661075 PMCid:PMC543384

Yang, J., Sears, R. G., Gill, B. S. and Paulsen, G. M. 2002. Growth and senescence characteristics associated with tolerance of wheat-alien amphiploids to high temperature under controlled conditions. Euphytica, 126: 185-193. https://doi.org/10.1023/A:1016365728633

Yildirim, M., Bahar, B., Koc, M. and Barutçular, C. 2009. Membrane thermal stability at different developmental stages of spring wheat genotypes and their diallel cross populations. Tarim Bilimleri Dergisi 15: 293-300. https://doi.org/10.1501/Tarimbil_0000001103

Yildirim, M., Kilic, H., Kendal, E. and Karahan, T. 2011. Applicability of chlorophyll meter readings as yield predictor in durum wheat. Journal of Plant Nutrition, 34: 151-164. https://doi.org/10.1080/01904167.2011.533319 